\title{
AN INVESTIGATION OF TOURISM EMPLOYEES' PERCEPTION OF WORKPLACE SPIRITUALITY IN TERMS OF DEMOGRAPHIC VARIABLES
}

\author{
Akın Aksu ${ }^{3}$ \\ Ömür Uçar ${ }^{4}$ \\ Rüya Ehtiyar ${ }^{5}$
}

\begin{abstract}
One of the most important social problems of the modern age is that working life is still far from human and spiritual values.At this point, the concept of "workplace spirituality" is an answer to this question as a new paradigm related to working life in social sciences. As research on the issue continues, the benefits of the concept for organizations, employees and employers are determined and scientific interest in spirituality-based approaches and practices is increasing in the context of the humanization of working life. This study aims to determine whether workplace spirituality of the employees working in tourism establishments differs according to demographic variables. In this context, quantitative research methods were employed and a total of 393 tourism employees were surveyed by using random sampling method. As a result of the study, a statistically significant difference was revealed in the participants' evaluation ofworkplace spirituality in terms of marital status, job position, income level, work experience, and educational background whileno significant difference was found in terms of age, gender and tourism education.
\end{abstract}

Key words: Business life, Spirituality, Workplace spirituality

\section{INTRODUCTION}

In management theories that aim to get the highest productivity from people, the understanding that proposes challenge to managers has already been abandoned. The search for new formulas continues for managers who seek more thanwhat is offered by the currently applied methods from the zero hierarchy that will "make them want to do" to participatory management approaches. One of the methods put forward in this framework and matured is the workplace spirituality approach, which suggests that spirituality should be considered as a management tool (Berzah and Çakır 2015). Research shows that managers, leaders and employees expect much more than economic returns in the workplace (Leigh, 1997: 28; Heaton et. al., 2004: 63; Fairholm, 1996: 11). Problems, risks and worries that undermine the trust environment

\footnotetext{
${ }^{3}$ Professor Akın Aksu Akdeniz, University Faculty of Tourism

${ }^{4}$ Assistant Professor Ömür Uçar Giresun, University Faculty of Tourism

${ }^{5}$ Associate Professor Rüya Ehtiyar Akdeniz, University Faculty of Tourism
} 
such as increasing competition in business life, stress, mobbing and job loss can both disturb the employer and the workforce. If a healthy and decent working life is desired by the parties, it is inevitable to apply to spiritual and moral values within the scope of the humanization of working life (Seyyar, 2009: 42). As a matter of fact, for the last 15 years, research has been determining the benefits of the concept to organizations, employees and employers, and in this context, scientific interest in spiritualityoriented approaches and practices has been increasing in the context of the humanization of working life (Giacalone and Jurkiewiez 2003, Mitroff and Denton 1999, Gavin and Mason 2004, Ashmos and Duchon, 2000), Badrinarayanan and Madhavaram, 2008).

In addition to a favourable organizational climate, themeaning of workplace spirituality coversvalues that are considered sacred by the noble, great people in the organizational environment. Organizational spirituality is a phenomenon that makes the abstract aspects of employees' working life meaningful (Çakıroğlu et al. 2018).

The concept of spirituality covers beliefs and practices that involve individuals' investing and strengthening their internal value judgments and make life more meaningful. When the concept of spirituality is considered or taken into consideration for the business world, organizational spirituality findsameaning as workplace spirituality or business spirituality (Akgemici et al. 2018). There is a lack of consensus among researchers over the definition of spirituality (Igbal and Hassan, 2016). In this study, it will be considered as the concept of workplace spirituality.

According to Seyyar (2009: 44), spirituality in the organizational dimension is the entire values accepted in labour relations and organizations. Dehler and Welsh (2003: 114), on the other hand, describe organizational spirituality as a search for meaning, in-depth recognition of self and/or progression to a higher level. The meaning of workplace spirituality covers the concepts of personal development, reliability and generosity, learning, responsibility, search for truth and meaning, reaching a high purpose, and mercy in working life (Freshman, 1999: 321). In this context, workplace spirituality requires people to establish a common conscience for a workplace that will enable them to establish a heartfelt relationship, show respect and sincere care for each other, develop reliable relationships and nurture this relationship (Neal and Biberman, 2003: 364). Similarly, Poole reveals that the workplace spirituality approach suggests evaluating employees not only with their bodies and minds, but also with their souls in the production process. According to Poole, if the approach of spirituality is adopted in the workplace, it is inevitable to have positive tangible results. As a matter of fact, this new approach from the west promises to turn problems into profit.

As a matter of fact, empirical and theoretical research on this issue and how spirituality works and affects the individual outcomes of the staff andorganizational implications are extensively increasing (Daniel 2012). Fry (2003: 703) states that there are many studies showing that organizations with a strong spiritual structure are more productive, flexible and creative. Organizational spirituality increases the managerial 
strength of the organization andpromotes leadership and organizational competitiveness and performance (Mitroff and Denton, 1999, Neal 1997, Pandey and Gupta 2008, Rego, Cunha and Oliveira 2008).

When employees have the opportunity to use their spiritual values astheyperformtheir tasks, their creativity increases and this makes them happy and more satisfied in their workplace (Mehran, 2017). Wainainaet al. (2014)'sresearch results indicatea significant positive relationship between workplace spirituality and organizational commitment. In their study, Neck and Milliman (1994)havefound that spirituality affects organizational performance positively. Creativity, satisfaction, team performance and also organizational commitment will increase in organizations thatpromote spirituality (Fanggidaeet al., 2015;Mousa and Alas, 2016; Litzsey, 2006; Luis Daniel, 2010). Similarly, workplace spirituality increases the level of employees' work engagement (Van der Walt's, 2017). Beehner and Blackwell (2016)'s research suggests that the increase in workplace spirituality decreases employee turnover rate. Lowder (2011)puts forward that developingspiritualityin the workplace guarantees a variety of outcomes related to organizational performance including high productivity, increased job satisfaction, high endorsement rates, positive ethical values, better attendance rates and high customer satisfaction. (cited in Berzah and Çakır 2015). For example, a study by Georgeanne Lamont has revealed that absenteeism and disease rates are much lower in the employees of spirit-friendly companies such as Happy Computers, Bayer UK, Nat West IMG, Microsoft UK, Scott Bader and Peach Personnel. Broadway Tires, a European company, has managed to reduce the absenteeism rate from 25-30\% to 2-3\% thanks to such spiritual practices (Berzah and Çakır, 2015). Barack (1999) believes that by creating an atmosphere of trust in the workplace, spirituality can be used as a tool to increase employee's commitment. Reave (2005)'s summary table demonstrating the relationship between spiritual values and variables such as understanding, tolerance, motivation, satisfaction, preservation, ethics and organizational citizenship behaviour is extremely striking. Similarly, Kazemipour et al. (2012) has found a positive relationship between workplace spirituality, organizational citizenship and organizational commitment. Spirituality is based on three principles (Igbal and Hassan, 2016), which are meaningful work or the aim of the work (individual level), having a sense of solidarity (group level), being in line with the values and mission of the organization (organizational level). Fig.1 shows the conceptualizations of workplace spirituality with these dimensions (Mehran, 2017). Milliman et al. (2003) examined the dimensions of organizational spirituality in three meaningful dimensions. These can be listed as meaningful work, having a sense of solidarity, and being in line with organizational values. 


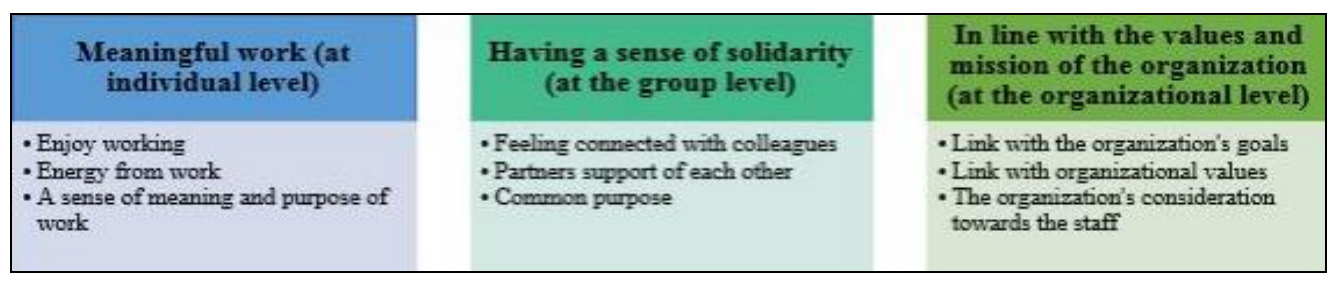

Fig. 1: The dimension of spirituality in the workplace (Milliam et al., 2003)

Meaningful Work: It gives employees a sense of purpose and meaning in the workplace. In other words, the work means something for the person. (Ashmos and Duchon, 2000; Guillory, 2001; Milliman et al., 2003, Fry, 2005). The work is claimed to be the most fundamental element in explaining spirituality. Therefore, employees'questions like "what is my purpose in working in this job?", "where does this work lead me?" explain this dimension of workplace spirituality (Örgev and Günalan, 2011).

Sense of Solidarity: Workplace spirituality is a framework which establishes the organizational culture that includes organizational values which give and facilitate the feelings of joy and belonging that employees share with each other. In this context, spirituality gives employees a sense of commitment and community (Karakaş, 2010).

Being in Line with the Organizational Values: This dimension refers to being in harmony with the organizational values within the organizational culture, corporate values, having a strong awareness and a work ethic based ontheorganizational values.

All the dynamics described above are also very closely related to tourism establishments, a very important branch of the service sector. As stated by Schmitt and Chan (1998), achieving high efficiency in the sector is only possible with qualified personnel who are identified with the establishment. This is because the fact that tourism employees feel happy in their work and whether they are motivated or not can have an impact on their overall workbehaviour and affect their performance at work. In addition, organizations now need employees who make contributions beyond expectations in order to make organizations more sustainable and achieve their goals. However,employees'willingnessto perform their duties and their abilities are not sufficient for the continuity of the establishments alone. A mutual strong emotional connection between the employees and the enterprise is necessary for the growth of the enterprises (Bolat and Bolat 2008: 76). This is because the need for the man and hence the labour force is not only economic/material but also spiritual. The labour force employed in today's working life and labour market cannot adequately meet these spiritual needs, alienates, loses the meaning of life and work, and sometimes does not even realize these needs in an intense, excessive and monotonous work order. Although a significant number of employees work and earn money, they cannot be 
happy enough, they feel the need to question their work, and they desire a job in which they assignameaning and find peace (Seyyar and Evkaya, 2015).

From this point of view, the study aims to determine whether employees' perceptions of workplace spirituality differ by demographic characteristics. In this context, the main question of the study is as follows: "Do the demographic characteristics (gender, marital status, age, educational background, work experience, job position, etc.) of the individuals involved in the study differentiate their perceptions of workplace spirituality?". It is hoped that the study will ensure the awareness of employees' perceptions of workplace spirituality and provide some clues about managing employees with different demographic characteristics in different ways.

\section{MATERIALS AND METHOD}

Quantitative research methods were used in the analysis of the data of this study which aimed to determine whether there were differences in tourism employees' perceptions of workplace spiritualitybased on their demographic characteristics such as gender, marital status, age and educational background. SPSS 22.0 program was used to statistically analyse the data obtained in the study. Descriptive statistics were shown as mean and standard deviation for the quantitative variables determined through measure, and as numbers and percentages for the ones determined through counting. Firstly, Shapiro-Wilk test was conducted to assess whether the data was normally distributed or not. As a result of the tests, it was concluded that the data showed normal distribution and parametric tests were used in statistical analysis. T-test was used in pairwise comparisons between two categorical variables such as gender and marital status, and variance analysis was used to determine the differences between three or more categorical variables such as income.

The universe of the research consists of tourism enterprises (hotels and travel agencies) operating in Antalya. In order to reach a higher number of data, convenience sampling method was preferred. In this context, face-to-face surveys were conducted with 393 people from April to October 2018, but 368 of these surveys were considered to be usable. Bryman and Cramer (2001) stated that it would be sufficient if the number of samples was at least 5 times the number of the items included in the survey (cited in Delice and Ergene, 2015: 64). There were a total of 21 itemsin the survey in the context of this research. Therefore, it is believed that the number of the samples is sufficient.

"Workplace Spirituality Scale" used in the study was developed by Ashmos and Duchon (2000) and adapted by Milliman et al. (2003) for their study. The scale includes sub-dimensions of meaningful work, having a sense of solidarity, and being in line with organizational values and consists of a total of three sub-dimensions and twenty-one items. The scale is entirely comprised of attitude expressions and 7-point Likert-type scale was used to measure these items (1- Strongly Disagree, 7-Strongly 
Agree). Cronbach's Alpha coefficient of the workplace spirituality scale was found to be 0.948 . Sadykova and Tutar (2014) determined the KMO value of the scale as ,882 in their validity analysis. Since the validity test of the scale was done before, it was not repeated.

\section{Findings}

Table 1 demonstrates that there was no statistically significant difference in the evaluations of workplace spirituality in terms ofthegender of the participants, $66,6 \%$ of whom were male ( $p>0.05)$.

Table 1: Independent Samples T Test Results according to Gender

\begin{tabular}{|l|l|c|c|c|c|c|}
\hline \multicolumn{2}{|c|}{} & $\mathrm{N}$ & Mean & $\begin{array}{c}\text { Std. } \\
\text { Deviation }\end{array}$ & T & P \\
\hline $\begin{array}{l}\text { Workplace } \\
\text { spirituality }\end{array}$ & Female & 128 & 5,15 & 1,13 & \multirow{2}{*}{$-0,289$} & \multirow{2}{*}{0,773} \\
\cline { 2 - 5 } & Male & 240 & 5,18 & 1,10 & & \\
\hline
\end{tabular}

Table 2 indicates that there was a statistically significant difference in theevaluations of workplace spirituality in terms of the marital status of the participants, $52 \%$ of whom were married ( $p<0,05$ ). Married participants had higher evaluations of workplace spirituality than single ones.

Table 2: Independent Samples T Test Results according to Marital Status

\begin{tabular}{|l|l|c|c|c|c|c|}
\hline \multicolumn{2}{|c|}{} & N & Mean & $\begin{array}{c}\text { Std. } \\
\text { Deviation }\end{array}$ & T & P \\
\cline { 1 - 5 } $\begin{array}{l}\text { Workplace } \\
\text { spirituality }\end{array}$ & Single & 175 & 5,04 & 1,12 & \multirow{2}{*}{$-2,319$} & \multirow{2}{*}{0,021} \\
\cline { 2 - 5 } & Married & 190 & 5,30 & 1,07 & & \\
\hline
\end{tabular}

As revealed in Table 3, 45,6\% of the participants received tourism education. No statistically significant difference was found in the evaluations of workplace spirituality based on whetherthe participants received tourism education or not $(\mathrm{p}>$ $0,05)$. 
Table 3: Independent Samples T Test Results according to Tourism Education

\begin{tabular}{|c|l|c|c|c|c|c|}
\hline \multicolumn{2}{|c|}{} & N & Mean & $\begin{array}{c}\text { Std. } \\
\text { Deviation }\end{array}$ & T & P \\
\hline \multirow{2}{*}{$\begin{array}{l}\text { Workplace } \\
\text { spirituality }\end{array}$} & Yes & 168 & 5,29 & 1,04 & \multirow{2}{*}{1,951} & \multirow{2}{*}{0,052} \\
\cline { 2 - 5 } & No & 199 & 5,07 & 1,15 & & \\
\hline
\end{tabular}

According to Table 4, there was a statistically significant difference in the evaluationsof workplace spirituality in terms oftheeducational background of the participants $(\mathrm{p}<0,05)$. The individuals with postgraduate education had the highest evaluations and the ones with associate degree had the lowest.

Table 4: Anova (F) Test Results according to Educational Background

\begin{tabular}{|l|l|l|l|l|l|l|}
\hline \multicolumn{2}{|c|}{} & \multicolumn{1}{|c|}{$\mathrm{N}$} & \multicolumn{1}{c|}{ Mean } & $\begin{array}{c}\text { Std. } \\
\text { Deviation }\end{array}$ & F & P \\
\hline \multirow{1}{*}{$\begin{array}{l}\text { Workplace } \\
\text { spirituality }\end{array}$} & $\begin{array}{l}\text { Primary } \\
\text { School }\end{array}$ & 55 & 5,20 & 1,12 & & \\
\cline { 2 - 5 } & High School & 138 & 5,10 & 1,22 & \multirow{2}{*}{3,190} & \multirow{2}{*}{0,014} \\
\cline { 2 - 5 } & $\begin{array}{l}\text { Associate } \\
\text { degree }\end{array}$ & 46 & 4,92 & 1,31 & \\
\cline { 2 - 5 } & $\begin{array}{l}\text { Bachelor's } \\
\text { degree }\end{array}$ & 107 & 5,20 & 0,84 & & \\
\cline { 2 - 5 } & $\begin{array}{l}\text { Postgraduate } \\
\text { degree }\end{array}$ & 17 & 5,99 & 0,50 & & \\
\cline { 2 - 5 } & Total & 363 & 5,16 & 1,11 & & \\
\hline
\end{tabular}

Table 5 shows that there was no statistically significant difference in the evaluations of workplace spirituality in terms of the age ranges of the participants. $(\mathrm{P}>0.05)$ 
Table 5: Anova (F) Test Results according to Age Range

\begin{tabular}{|c|c|c|c|c|c|c|}
\hline & & $\mathrm{N}$ & Mean & $\begin{array}{c}\text { Std. } \\
\text { Deviation }\end{array}$ & $\mathrm{F}$ & $\mathrm{P}$ \\
\hline \multirow[t]{6}{*}{$\begin{array}{l}\text { Workplace } \\
\text { spirituality }\end{array}$} & $\begin{array}{l}20 \text { yearsand } \\
\text { below }\end{array}$ & 17 & 4,63 & 1,38 & \multirow{6}{*}{1,615} & \multirow{6}{*}{0,171} \\
\hline & $21-30$ & 148 & 5,13 & 1,12 & & \\
\hline & $31-40$ & 134 & 5,19 & 1,03 & & \\
\hline & $41-50$ & 55 & 5,37 & 1,18 & & \\
\hline & Above 50 & 14 & 5,38 & 0,96 & & \\
\hline & Total & 368 & 5,17 & 1,11 & & \\
\hline
\end{tabular}

As can be seen in Table 6, there was a statistically significant difference in the evaluations of workplace spirituality in terms ofthe work experience of the participants $(\mathrm{p}<0.05)$. The highest evaluation was for the individuals with work experience of 10 years or more and the lowest was for the ones with work experience of 1 year or less. Based on Table 6, it can be suggested that as the work experience of the participants increased, so didtheirworkplacespirituality.

Table 6: Anova (T) Test Results according to Work Experience

\begin{tabular}{|c|c|c|c|c|c|c|}
\hline \multicolumn{2}{|c|}{ Work experience } & $\mathrm{N}$ & Mean & $\begin{array}{c}\text { Std. } \\
\text { Deviation }\end{array}$ & $\mathrm{F}$ & $\mathrm{P}$ \\
\hline \multirow[t]{5}{*}{$\begin{array}{l}\text { Workplace } \\
\text { spirituality }\end{array}$} & $\begin{array}{l}1 \text { yearand } \\
\text { less }\end{array}$ & 43 & 4,87 & 1,22 & \multirow{5}{*}{3,816} & \multirow{5}{*}{0,01} \\
\hline & $2-5$ years & 116 & 4,99 & 1,17 & & \\
\hline & 6-9 years & 94 & 5,33 & 1,00 & & \\
\hline & $\begin{array}{l}10 \text { years and } \\
\text { more }\end{array}$ & 115 & 5,34 & 1,03 & & \\
\hline & Total & 368 & 5,17 & 1,11 & & \\
\hline
\end{tabular}

According to Table 7, 73.3\% of the participants had an income of 1501-2500 TL. There was a statistically significant difference in the evaluations of workplace spirituality in terms ofthe income level of the participants $(\mathrm{p}<0.05)$. The highest evaluation was for those with an income of $4501 \mathrm{TL}$ and above, and the lowest was for the ones who had an income of 1501-2500 TL. According to Table 7, it is clear that as the income level of the participants increased, their workplace spirituality did, too. 
Table 7: Anova (F) TestResultsaccording to Income Level

\begin{tabular}{|c|c|c|c|c|c|c|}
\hline \multicolumn{2}{|c|}{ Income level } & $\mathrm{N}$ & Mean & $\begin{array}{c}\text { Std. } \\
\text { Deviation }\end{array}$ & F & $\mathrm{P}$ \\
\hline \multirow{5}{*}{$\begin{array}{l}\text { Workplace } \\
\text { spirituality }\end{array}$} & $1501-2500 \mathrm{TL}$ & 270 & 5,10 & 1,17 & \multirow{5}{*}{3,776} & \multirow{5}{*}{0,011} \\
\hline & $2501-3500 \mathrm{TL}$ & 64 & 5,19 & 0,95 & & \\
\hline & $3501-4500 \mathrm{TL}$ & 14 & 5,52 & 0,77 & & \\
\hline & $\begin{array}{l}4501 \mathrm{Tl} \text { and } \\
\text { more }\end{array}$ & 20 & 5,89 & 0,53 & & \\
\hline & Total & 368 & 5,17 & 1,11 & & \\
\hline
\end{tabular}

Table 8 indicates that there was a statistically significant difference in the evaluations of workplace spirituality according to thejobpositions of the participants in the workplace $(\mathrm{p}<0,05)$. The highest evaluations belonged to the managers and the lowest ones belonged to the workers. According to Table 8, it was found that as the job position of the participants increased, theirworkplacespirituality did, too.

Table 8: Anova (F) Test Results according to Job Position

\begin{tabular}{|c|c|c|c|c|c|c|}
\hline \multicolumn{2}{|c|}{ Job Position } & N & Mean & $\begin{array}{c}\text { Std. } \\
\text { Deviation }\end{array}$ & F & P \\
\hline \multirow{3}{*}{$\begin{array}{l}\text { Workplace } \\
\text { spirituality }\end{array}$} & Worker & 247 & 5,08 & 1,18 & & \multirow{2}{*}{5,814} \\
\cline { 2 - 5 } & Supervisor & 89 & 5,22 & 0,96 & \multirow{2}{*}{0,003} \\
\cline { 2 - 5 } & Manager & 32 & 5,77 & 0,62 & & \\
\cline { 2 - 5 } & Total & 368 & 5,17 & 1,11 & & \\
\hline
\end{tabular}

\section{CONCLUSION AND DISCUSSION}

The approach of workplace spirituality, which proposes a management based on spirituality for employers and managers with the promise of achieving tangible results such as higher productivity, more profits, and decrease in employee problems, reminds employees of the sanctity of work and working and promises to seek and reach happiness by trying to understand the meaning of its existence. When the main problem areas of tourism sector are examined, conditions of layoffs, company downsizing, changes caused by competition, stress and burnout experienced by the employees who have to work harder for less wages, job dissatisfaction, increasing employee turnover etc. are frequently observed. This situation prevents a significant part of the employees from being happy and makes them feel the need to question the work they do, thus leading to low productivity and performance in the workplace. 
One of the most important arguments in providing service quality in hospitality and travel establishments is labour. Therefore, it is extremely important to create highly motivated and committed employees in the sector and to keep them in business. At this point, it is possible to get the optimum benefit from human resources (labour force) and increase organizational performance thanks to spirituality-oriented managerial practices and business approach. Therefore, workplace spirituality is one of the important issues that need to be emphasized. The scarcity of the scientific studies on "workplace spirituality" in Turkey has been the motive for this study. Whether demographic factors have any effect on tourism employees' perceptions of organizational dynamics has been an issue focused on by the researchers in the relevant literature. In this study, whether the demographic characteristics (gender, marital status, age, educational background, work experience, position held, etc.) of the individuals working in hospitality and travel establishments made a difference in their perceptions of workplace spirituality was determined. Theresearch results can be specifiedas follows.

$\checkmark$ There was no statistically significant difference in the evaluations of workplace spirituality in terms of the gender of the participants. This situation shows that male and female employees had similar perceptions of workplace spirituality.

$\checkmark$ There was a statistically significant difference in the evaluations of workplace spirituality in terms ofthemarital status of the participants. Married participants had higher workplace spirituality evaluations than single ones.

$\checkmark$ There was no statistically significant difference in the evaluations of workplace spirituality in terms of the tourism education of the participants.

$\checkmark$ There was a statistically significant difference in the evaluations of workplace spirituality in terms oftheeducational background of the participants.

The individuals with postgraduate education had the highest evaluations and the ones with associate degree had the lowest. In our study, it was found that employees with postgraduate education had significantly higher workplace spirituality compared to the ones with associate degree education. Considering that the opinions about workplace spirituality get more positive as the education level increases, the situation in the tourism sector should be re-questioned by the managers, the improvement efforts should be accelerated and research should be conducted on the issue.

$\checkmark$ There was no statistically significant difference in the evaluations of workplace spirituality in terms of the age ranges of the participants. This shows that the employees in different age ranges had similar perceptions of workplace spirituality.

$\checkmark$ There was a statistically significant difference in the evaluations of workplace spirituality in terms ofthe work experience of the participants. The highest evaluation was for the individuals with work experience of 10 years or more and the lowest was for the ones with work experience of 1 year or less. It can 
be claimed that as the work experience of the participants increased, so did their workplace spirituality.

$\checkmark$ There was a statistically significant difference in the evaluations of workplace spirituality in terms ofthe income level of the participants. It is seen that as the income level of the participants increased, their workplace spirituality increased as well. This result shows that better wages can be effective in increasing workplace spirituality.

$\checkmark$ There was a statistically significant difference in the evaluations of workplace spirituality according to the job positions of the participants in the workplace. The highest evaluation belonged to the managers and the lowest one belonged to the workers. It was revealed that as the job position of the participants increased, their workplace spirituality increased, too.

\section{LIMITATIONS OF THE STUDY, FUTURE STUDIES AND RECOMMENDATIONS FOR TOURISM ENTERPRISES}

The most important limitation of the study is that it consisted only of people working in five-star hospitality and travel establishments. Another limitation is that it was conducted only in the Antalya region. Future studies can be carried out in different regions, different hospitality and travel establishments, and comparisons can be made.Inaddition, it may be useful to re-conduct the study in different cultures and establishmentsto be able to interpret broadly.

It is hoped that the study will ensure the awareness of employees' perceptions of workplace spirituality and provide some clues about managing employees with different demographic characteristics in different ways. In this context, it is believed that the development of management strategies for demographic characteristics that differentiate hospitality and travel employees' perceptions of workplace spirituality will affect the performance and productivity of the establishments positively. In addition, the study is expected tocontribute to the literature by being a resource for the research to be conducted on the effects of the concept of workplace spirituality. 


\section{REFERENCES}

1. Akgemci, T., Kaplan, M. and Turak Kaplan, B., (2018).Örgütsel Maneviyatın Iş Stresi Üzerine Etkisinde Örgütsel Güvenin Aracılık Rolü: Konya Organize Sanayi Bölgesi’nde Bir Araştırma, 4(19), 311-319.

2. Ashmos, D. and Duchon, D. (2000). Spirituality at Work: A Conceptualization and Measure, Journal of Management Inquiry, 9, 134-145.

3. Badrinarayanan, V. and Madhavaram, S. (2008). Workplace Spirituality and the Selling Organization: A Conceptual Framework and Research Propositions. Journal of Personal Selling and Sales Management, 28(4), 421434.

4. Beehner, C. G., and Blackwell, M. J. (2016).The Impact of Workplace Spirituality on Food Service Worker Turnover Intention. Journal of Management, Spirituality \& Religion, 13(4), 304-323.

5. Berzah, M. Ç. and Çakır, M. (2015). İş Hayatında Maneviyat Yaklaşımı Ne Vaadediyor?. Yönetim Bilimleri Dergisi, 13(26), 135-149.

6. Bolat, O.D and Bolat, T. (2008). Otel İşletmelerinde Örgütsel Bağl1lıkve Örgütsel Vatandaşlık Davranışı İlişkisi, Balıkesir Üniversitesi Sosyal Bilimler Enstitüsü Dergisi, 11(19), 75- 94.

7. Burack, E. H. (1999). Spirituality in the Workplace. Journal of Organizational Change Management, 12(4), 280-291.

8. Çakıroğlu, D., Aydoğan, E. and Işıkhan, S.H. (2018).Kamuve Özel Kesim Çalışanlarının Örgütsel Maneviyat Algıları: Bir Alan Araştırması.International Refereed \& Indexed Journal of Social Sciences, 4(13), 1065-1073.

9. Daniel, J.L. (2010). The Effect of Workplace Spirituality on Team Effectiveness. Journal of Management Development, 29(5), 442-456.

10. Dehler, G. E. and Welsh, M. A.. (1994). Spirituality and Organizational Transformation: Implications for The New Management Paradigm, Journal of Managerial Psychology, 9 (6), 17-26.

11. Delice, A. Ve Ergene, Ö. (2015). "Investigation of Scale Development and Adaptation Studies: An Example of Mathematics Education Articles". Karaelmas Journal of Educational Sciences, 3: 60-75.

12. Djafri, F., and Noordin, K. (2017). The Impact of Workplace Spirituality on Organizational Commitment. Humanomics, 33(3), 384-396.

13. Fairholm, G. W. (1996). Spiritual Leadership: Fulfilling Whole-Self Needs at Work. Leadership \& Organizational Development Journal, 17 (5), 11-17.

14. Fanggida, E., Rolland, E., Suryana, Y. and Hilmiana, N.E. (2016). Effect of Spirituality Workplace on Organizational Commitment and Job satisfaction, Procedia - Social and Behavioral Sciences, 219, 639-646. 
15. Freshman, B. (1999). An Exploratory Analysis of Definitions and Applications of Spirituality in The Workplace, Journal of Organizational Change Management, 12 (4), 318-327.

16. Fry, L. W. (2003). Toward a Theory of Spiritual Leadership, The Leadership Quarterly, 14, 693-727.

17. Gavin, J. H. and Mason, R.O. (2004). The Virtuous Organization: The Value of Happiness in the Workplace, Organizational Dynamics, 33(4), 379-392.

18. Giacalone, R. A. and Jurkiewicz, C. L. (2003). Toward a Science of Workplace Spirituality, Armonk, New York: M. E. Sharpe, Inc. Spirituality. Giacalone, R. A. and Jurkiewicz, C. L. (Editors), Handbook of Workplace Spirituality and Organizational Performance, 3-29.

19. Heaton, D. P., Schimidt-Wilk, J. and Travis, F. (2004).Constructs, Methods and Measures for Researching Spirituality in Organizations. Journal of Organizational Change Management, 17 (1), 62-82.

20. Iqbal, Q. and Hassan, S. H. (2016). Role of Workplace Spirituality: Personality Traits and Counterproductive Workplace Behaviors in Banking Sector, International Journal of Management, Accounting and Economics, 3(12), 806-821.

21. Karakaş, F. (2010). “Spirituality and Performance in Organizations: A Literature Review”, Journal of Business Ethics, 94(1), 89-106.

22. Kazemipour, F. and Mohd Amin, S. (2012), The Impact of Workplace Spirituality Dimensions on Organisational Citizenship Behaviour among Nurses with the Mediating Effect of Affective Organisational Commitment, Journal of Nursing Management, 20(8), 1039-1048.

23. Leigh, P. (1997). The New Spirit at Work. Training \& Development, 51 (3), 26-41.

24. Mehran, Z. (2017). The Effect of spirituality in the workplace on organizational commitment and organizational citizenship behavior, Int. J. Hum. Capital Urban Manage., 2(3), 219-228.

25. Milliman, J., Czaplewski, A.J., and Ferguson, J. (2003). Workplace Spirituality and Employee Work Attitudes: An Exploratory Empirical Assessment. Journal of Organizational Change Management, 16(4), 426-447.

26. Mitroff, I. I. and Denton, E. A. (1999). A Study of Spirituality in the Workplace, Sloan Management Review, 40, 83-92.

27. Mousa, M. and Alas, R. (2016). Workplace Spirituality and Organizational Commitment: A Study on the Public Schools Teachers in Menoufia (Egypt), African Journal of Business Management, 10(10), 247-255.

28. Neal, J. and Biberman, J. (2003), "Introduction: The Leading Edge in Research on Spirituality and Organizations", Journal of Organizational Change Management, 16(4), 363-366. 
29. Neck, C. P. and Milliman, J. F., 1994. Thought self-leadership: Finding spiritual fulfillment in organizationallife.Journal of Managerial Psychology, 6, 9-16.

Örgev, M. and Günalan, M. (2011). İşyeri Maneviyatı Üzerine Eleştirel Bir Değerlendirme. Kahramanmaraş Sütçü İmam Üniversitesi İ.İ.B.F. Dergisi, 2, 51-64.

30. Pandey, A., Gupta, R. K., and Arora, A. P. (2008). Spiritual Climate of Business Organizations and Its Impact on Customers' Experience. Journal of Business Ethics, 88(2), 313-332.

31. Reave, L. (2005). Spiritual values and practices related to leadership effectiveness. The Leadership Quarterly, 16(5), 655-687.

32. Rego, A. and Pinae Cunha, M. (2008). Workplace Spirituality and Organizational Commitment: An Empirical Study", Journal of Organizational Change Management Dynamics, 21(1), 53-75.

33. Sadykova, G., and Tutar, H. (2014). İşyeri Maneviyatıve Örgütsel Güven Arasındaki İlişki Üzerine Bir Araştırma, Journal of Turkish Court of Accounts / Sayistay Dergisi, 93, 43-65.

34. Schmitt, Neal, and Chan D.. (1998). Personnel Selection: A Theoretical Approach. Thousand Oaks, CA: SAGE.

35. Seyyar A. and Evkaya, C. (2015). Batıda İşyeri Maneviyatı Alanında Yapılan Bilimsel Çalışmaların Türk Bilim Camiasına Etkileri, Siyaset, Ekonomive Yönetim Araştırmaları Dergisi, 16. Çalı̧̧ma Ekonomisive Endüstri İlişkileri Kongresi Özel Sayıs1.

36. Seyyar, A. (2009). Çalışma Hayatındave İşyerinde Maneviyat. Kamuda Sosyal Politika, 3 (11), 42-52.

37. Van der Walt, F. (2018). Workplace spirituality, work engagement and thriving at work. SA Journal of Industrial Psychology, 44.1-10.

38. Wainaina, L., Iravo, M. and Waititu, A. (2014). Workplace Spirituality as a Determinant of Organizational Commitment amongst Academic Staff in the Private and Public Universities in Kenya, International Journal of Academic Research in Business and Social Sciences, 4(12), 280-293. 